\title{
In memorium, Chester Monroe Edelmann, Jr., MD December 26, 1930-September 19, 2013
}

\author{
Adrian Spitzer • Rick Kaskel
}

Received: 8 April 2014 /Revised: 8 April 2014 / Accepted: 11 April 2014 / Published online: 3 May 2014

(C) IPNA 2014

Chester M. Edelmann, Jr., MD, Senior Associate Dean and Most Distinguished University Professor of Pediatrics, Albert Einstein College of Medicine, belonged to the best among us. Born in New York City in 1930, "Chet" went to Columbia College, then to Washington University in St. Louis, and then he returned to finish medical school at Cornell University and married his sweetheart Norma. He followed Henry Barnett, the first Chair of Pediatrics at Bronx Municipal Hospital Center, the teaching hospital of the newly created Albert Einstein College of Medicine, became Chief Resident, and thereafter accepted a position in nephrology. In a landmark Journal of Clinical Investigation article, Chet and his colleagues demonstrated that a high protein intake led not only to an increase in urea and water excretion but also to an increase in concentration capacity that almost wiped out the difference previously noted between infants and children.

He then served as Staff Pediatrician at the U.S. Naval Hospital, in Portsmouth, VA., and rose to the rank of Lieutenant Commander. He returned to the Bronx and with collaborators (Soriano, Boichis, Acosta, Stark, and Gruskin) demonstrated that rates of excretion of titratable acid and ammonium were somewhat different in infants and children, but net acid secretion was not significantly different in the two groups. Thus, it was demonstrated that the ability of the infant to dispose of an acid load was adequate. They next determined that the bicarbonate threshold in infants was lower than in adults (at about 22 mmoles per liter), which facilitated the identification of proximal renal tubular acidosis.

A number of articles dealing with various aspects of developmental renal physiology or pathophysiology followed, and

\footnotetext{
A. Spitzer $\cdot$ R. Kaskel $(\bowtie)$

Division of Pediatric Nephrology, Albert Einstein College of Medicine, Children's Hospital at Montefiore, Bronx, NY, USA e-mail: fkaskel@aecom.yu.edu
}

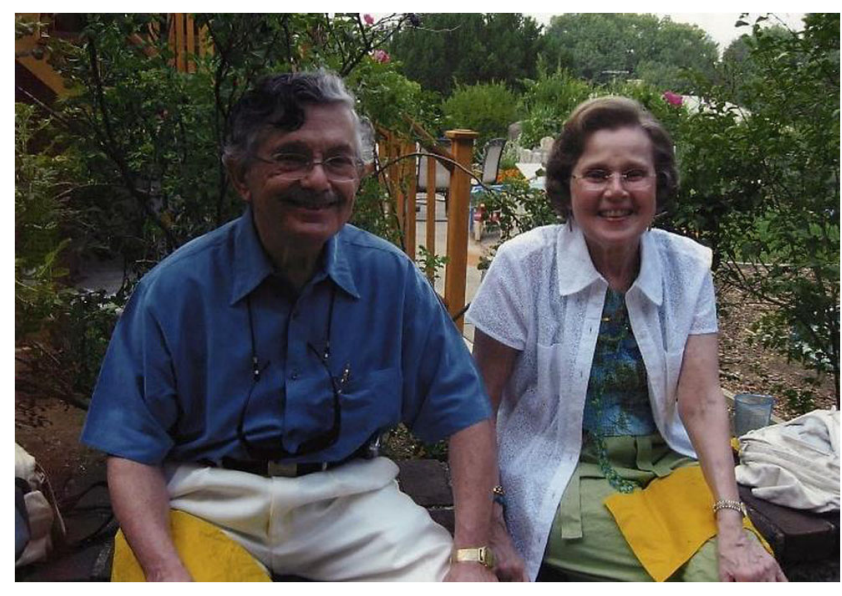

in 1969, Chet was elected into the Society of Clinical Investigation, a distinguished fraternity almost exclusively reserved to internists. By then, he was the Chief of the Division of Nephrology, an Associate Professor of Pediatrics, a member of the Society for Pediatric Research, and a recipient of an NIH Research Career Development Award. In 1972, Chet received the Mead Johnson Award conferred by the American Academy of Pediatrics. That same year, Henry Barnett became Associate Dean and, shortly thereafter, Chet Edelmann succeeded him as Chairman of the Department. In 1976 he edited one of the first textbooks of pediatric nephrology.

In 1980, Chet became Associate Dean. The American Society of Pediatric Nephrology honored Chet with the Founder's Award for his years of service and dedication to this growing society. These tributes carry the sentiments of hundreds of people who have benefited from the many contributions he made to academic pediatrics and pediatric nephrology, and most importantly, to our Society.

Chet is survived by his adoring wife of 60 years, Norma, three loving children: John, Christopher, and Kathy, and his granddaughter, Jessica. He is also survived by his sister, Maida Heitner, and her family. He is 
the son of the late Nannette Lenore Edelmann and Chester Monroe Edelmann, Sr. Chet was a true Renaissance man; a lover of languages and their usage: a concert level pianist; a faithful patron of opera, the theatre, and the philharmonic. He created fine furniture, was a loyal Mets fan, and enjoyed simple beauty. $\mathrm{He}$ was devoted to his wife and family, his patients, his church, science, his community, and his country. $\mathrm{He}$ believed in excellence, honesty, integrity, and above all, compassion. Chet was a rare man, contemplative, yet effective, who quietly found success in the improved health of his patients, in the happiness of his children, and in the achievements of his students and colleagues. Chet touched the lives of countless people in many countries worldwide and will be missed by all, but most of all by his wife and children. 